\title{
Arsenic trioxide inhibits DNA methyltransferase and restores expression of methylation-silenced CDKN2B/CDKN2A genes in human hematologic malignant cells
}

\author{
HAI-YING FU, JIAN-ZHEN SHEN, YONG WU, SONG-FEI SHEN, HUA-RONG ZHOU and LI-PING FAN \\ Fujian Institute of Hematology, Union Hospital, Fujian Medical University, Fuzhou, Fujian 350001, P.R. China
}

Received March 9, 2010; Accepted April 12, 2010

DOI: $10.3892 /$ or_00000864

\begin{abstract}
Cyclin-dependent kinase inhibitors CDKN2B and CDKN2A are tumor suppressor genes that are frequently dysregulated in a variety of cancers. Aberrant regulation via DNA hypermethylation causes gene silencing. Arsenic trioxide has been successfully used to treat malignant, hematopoietic diseases and is known to act by induction of apoptosis and inhibition of cellular proliferation. However, arsenic trioxide has been recently reported to act via inhibition of DNA hypermethylation in some solid tumors. The goal of this study was to explore the mechanism of arsenic trioxide induced demethylation of the CDKN2B and CDKN2A promoters in the hematologic malignant cell lines Molt4, MUTZ-1, U937, U266 and CA46. We used bisulphate modification and nested-methylation specific PCR to determine the levels of methylated and unmethylated promoter sequences in untreated and $\mathrm{As}_{2} \mathrm{O}_{3}$-treated cells. We used semi-quantitative RT-PCR and immunoblotting to quantify CDKN2B and CDKN2A mRNA and protein levels, respectively. We measured DNMT activity in nuclear extracts of untreated and treated cells using radiolabeled SAM as a methyl donor. The CDKN2B promoter was hypermethylated in Molt4 and MUTZ-1 cells, while the CDKN2A promoter was hypermethylated in U937, U266 and CA46 cells. $\mathrm{As}_{2} \mathrm{O}_{3}$ treatment caused demethylation associated with an increase in mRNA levels of the CDKN2B and CDKN2A genes. We also demonstrated a concomitant inhibition in DNMT activity and DNMT mRNA levels in $\mathrm{As}_{2} \mathrm{O}_{3}$-treated cells. In summary, $\mathrm{As}_{2} \mathrm{O}_{3}$ restored expression levels of tumor suppressor genes in hematologic malignant cells by causing promoter demethylation along with an inhibition of DNMTs $1,3 \mathrm{a}$ and $3 \mathrm{~b}$.
\end{abstract}

Correspondence to: Dr Jian-Zhen Shen, Fujian Institute of Hematology, Union Hospital, Fujian Medical University, Fuzhou, Fujian 350001, P.R. China

E-mail: bruce@medmail.com.cn

Key words: methylation, arsenic trioxide, hematologic malignancies, gene reactivation, CDKN2B and CDKN2A genes

\section{Introduction}

Cell cycle progression is a tightly regulated process that governs cell size, genomic integrity and coordination of multiple cellular signaling events $(1,2)$. Dysregulation of the cell cycle is the hallmark of tumor development. Cyclindependent kinases and their cyclin partners are important positive regulators accelerating the progression of the cell cycle while the cyclin-dependent kinase inhibitors act as negative regulators. The CDKN2B (p15) and CDKN2A (p16) genes located on chromosome 9p21, are two important cyclindependent kinase inhibitors which are known to be frequently mutated or deleted in a wide variety of cancers (2). Loss of expression of these genes confers a growth advantage to a number of tumors leading to these genes being classified as candidate tumor suppressor genes. Inactivation of tumor suppressors such as CDKN2B and CDKN2A is commonly seen in all forms of human cancer (1). Such inactivation of tumor suppressor genes can result from deletions, point mutations as well as reversible epigenetic events such as promoter hypermethylation $(3,4)$. Tumor suppressor genes are frequently silenced by $\mathrm{CpG}$ island methylation in a number of cancers, including hematologic malignancies and solid tumors $(5,6)$.

CDKN2B and CDKN2A specifically inhibit cyclindependent kinases CDK4 and CDK6. Their expression is induced by transforming growth factor TGFß. The CDKN2B and CDKN2A genes have been reported to be frequently methylated in hematological malignancies (5) and these cells are thought to evade TGFß regulation via this hypermethylation event.

Arsenic trioxide $\left(\mathrm{As}_{2} \mathrm{O}_{3}\right)$ has recently been found to be effective in the treatment of malignant hematopoietic diseases through induction of apoptosis and inhibition of cellular proliferation $(7,8)$. It has been used to treat acute promyelocytic leukemia and multiple myeloma with good results, but showed equivocal results in a phase II trial for metastatic colon cancer (9). It did not produce complete remission in renal cell carcinoma, metastatic melanoma or germ cell malignancies reflecting possible differences in pathogenesis, mechanism of genetic abnormalities and mechanism of tumor response to arsenic between solid tumors and hematological tumors (9). Arsenic trioxide has been reported to utilize S-adenosyl methionine (SAM) $(8,10)$, an essential co-factor of DNMTs (11), in order to bring about DNA hypomethylation. $\mathrm{As}_{2} \mathrm{O}_{3}$ 
Table I. Primer sequence, length and annealing temperature of n-MSP and RT-PCR.

\begin{tabular}{|c|c|c|c|}
\hline Primer & Sequence & Length & $\begin{array}{c}\text { Annealing } \\
\text { temperature }\left({ }^{\circ} \mathrm{C}\right)\end{array}$ \\
\hline Actin $1(\mathrm{~S})$ & 5'-GTGGGGCGCCCCAGGCACCA-3' & 517 & Changeable \\
\hline Actin 1 (AS) & 5'-CTCCTTAATGTCACGCACGATTTC-3' & & \\
\hline Actin $2(\mathrm{~S})$ & 5'-CGAGAAGATGACCCAGATCA-3' & 234 & Changeable \\
\hline Actin 2 (AS) & 5'-GATCTTCATGAGGTAGTCAG-3' & & \\
\hline CDK2BM (S) & 5'-GGTTTTAAGTCGTAGAAGGACGAC-3' & & \\
\hline CDK2BM (AS) & 5'-GGTTATTGTACGGGGTTTTAAGTC-3' & 194 & 59 \\
\hline CDK2BU (S) & 5'-GGGTTTTAAGTTGTAGAAGGATGAT-3' & 196 & 59 \\
\hline CDK2BU (AS) & 5CСАCСССАAАCCACAACCATAA3 & & \\
\hline CDKN2AM (S) & 5'-TTATTAGAGGGTGGGGCGGATCGC-3' & 150 & 65 \\
\hline CDKN2AM(AS) & 5'-GACCCCGAACCGCGACCGTAA-3' & & \\
\hline CDKN2AU(S) & 5'-TTATTAGAGGGTGGGGTGGATTGT-3' & 151 & 65 \\
\hline CDKN2AU(AS) & 5'-CCACCCCAAACCACAACCATAA-3' & & \\
\hline $\mathrm{CDKN} 2 \mathrm{~B}(\mathrm{~S})$ & 5'-TGGGGGCGGCAGCGATGAG-3' & 450 & 57 \\
\hline CDKN2B(AS) & 5'-AGGTGGGTGGGGGTGGGAAAT-3' & & \\
\hline $\mathrm{CDKN} 2 \mathrm{~A}(\mathrm{~S})$ & 5'-TTATTTGAGCTTTGGTTCTG-3' & 355 & 54 \\
\hline CDKN2A(AS) & 5'-CCCGCTTTCGTAGTTTTCAT-3' & & \\
\hline $\operatorname{DNMT1}(\mathrm{S})$ & 5'-ACCATCACATCTCATTTTGC-3' & 238 & 56 \\
\hline DNMT1(AS) & 5'-GGTTTGACTTCGGAGTCTCT-3' & & \\
\hline DNMT3A(S) & 5'-CACACAGAAGCATATCCAGGAGTG-3' & 551 & 55 \\
\hline DNMT3A(AS) & 5'-AGTGGACTGGGAACCAAATACCC-3' & & \\
\hline DNMT3B(S) & 5'-AATGTGAATCCAGCCAGGAAAGGC-3' & 190 & 55 \\
\hline DNMT3B(AS) & 5'-ACTGGATTACACTCCAGGAACCGT-3' & & \\
\hline
\end{tabular}

may therefore play a role in the regulation of tumor suppressor genes by interfering with DNA methylation patterns.

We explored the status of CDKN2B and CDKN2A promoter hypermethylation in $\mathrm{As}_{2} \mathrm{O}_{3}$-treated human hematological malignancy cells, Molt4, U937, MUTZ-1, U266 and CA46. We also explored the possibility of manipulating the expression of the CDKN2B and CDKN2A genes in these cells by $\mathrm{As}_{2} \mathrm{O}_{3}$-mediated demethylation of $\mathrm{CpG}$ islands in the CDKN2B and CDKN2A promoters. Finally, we investigated the levels of DNA methyl transferases DNMT1, DNMT3a and DNMT3b in untreated and $\mathrm{As}_{2} \mathrm{O}_{3}$-treated cells to determine the mechanism of gene regulation by $\mathrm{As}_{2} \mathrm{O}_{3}$-mediated hypomethylation in these cells.

\section{Materials and methods}

Cell lines and reagents. Molt4 (an acute lymphoblastic leukemia cell line), U937 (an acute myelocytic leukemia cell line), MUTZ-1 (a myelodysplastic syndromes (MDS) cell line), U266 (a multiple myeloma cell line) and CA46 (a malignant lymphoma cell line) were obtained from the Wuhan Cell Bank (Wuhan, China). Cells were routinely cultured in RPMI-1640 (Gibco) supplemented with 10\% heat-inactivated FBS (Shijiqing, Biosciences, Hangzhou, China) and incubated at $37^{\circ} \mathrm{C}$ with $5 \% \mathrm{CO}_{2}$ in a humidified atmosphere. $\mathrm{As}_{2} \mathrm{O}_{3}$
(Sigma, St. Louis, MO, USA) was dissolved in a small amount of $1.0 \mathrm{~mol} / \mathrm{l} \mathrm{NaOH}$, then diluted to $10 \mathrm{mmol} / \mathrm{l}$ with phosphatebuffered saline (PBS) as stock solution. Cells $\left(1 \times 10^{5} / \mathrm{ml}\right)$ were treated with $0.5,1.0$ and $2.0 \mu \mathrm{mol} / 1$ of $\mathrm{As}_{2} \mathrm{O}_{3}$. In addition to untreated cells, normal human bone marrow cells from spina iliaca posterior superior were used as a control.

Bisulfite modification and nested-methylation specific polymerase chain reaction ( $n-M S P)$. Genomic DNA was extracted from Molt4, U937, MUTZ-1, U266 and CA46 cell lines using a DNeasy Tissue kit (Qiagen, Valencia, CA). DNA was modified using sodium bisulfite as previously described (12). Bisulfite treatment of DNA converts unmethylated cytosine residues into uracil, but methylated cytosine residues remain unmodified (12). Briefly, $2 \mu \mathrm{g}$ of genomic DNA was denatured in $0.2 \mathrm{~N} \mathrm{NaOH}$ at $37^{\circ} \mathrm{C}$ for $10 \mathrm{~min}$ and incubated with $3 \mathrm{M}$ sodium bisulfite at $50^{\circ} \mathrm{C}$ for $15 \mathrm{~h}$. The DNA was then purified using the Wizard DNA Clean-Up System (Promega, Madison, WI, USA), and desulfonated in $0.3 \mathrm{~N} \mathrm{NaOH}$ at $25^{\circ} \mathrm{C}$ for $5 \mathrm{~min}$. DNA was precipitated with ammonium acetate and ethanol, washed with $70 \%$ ethanol, and resuspended in $20 \mu 1 \mathrm{H}_{2} \mathrm{O}$.

Primer sequences used to amplify methylated (M-MSP) and unmethylated (U-MSP) promoters of CDKN2B and CDKN2A are shown in Table I. Polymerase chain reaction 
(PCR) was performed in a final reaction volume of $25 \mu 1$ containing $2.5 \mu 110 \mathrm{X}$ buffer, $0.25 \mathrm{mmol} / \mathrm{l} \mathrm{dNTPs}, 0.25 \mathrm{pmol}$ primers, $2.5 \mathrm{U}$ of Taq polymerase (Takara) and $50 \mathrm{ng}$ of bisulphate-treated DNA. PCR was performed in an automated thermal cycler (9700; PE Biosystems) as follows: $95^{\circ} \mathrm{C}$ for $12 \mathrm{~min}$; 35 cycles of $95^{\circ} \mathrm{C}$ for $45 \mathrm{sec}$, specific annealing temperature (Table I) for $30 \mathrm{sec}$ and $72^{\circ} \mathrm{C}$ for $30 \mathrm{sec}$ and a final extension of $10 \mathrm{~min}$ at $72^{\circ} \mathrm{C}$.

DNA sequence analysis of methylated $C D K N 2 B$ and $C D K N 2 A$ genes. The MSP PCR product of the CDKN2B and CDKN2A genes were recovered by using gel recovering kit, cloned in the PMD-18-T vector (Takara, Ltd.) and sequenced by BioAsia, Ltd.

Reverse transcriptase-polymerase chain reaction (RT-PCR). Total RNA was extracted from $2-5 \times 10^{6}$ cells using TRIzol (Life Technologies, USA) according to the manufacturer's recommendations. Reverse transcription was performed using $2 \mu \mathrm{g}$ total RNA, $500 \mathrm{ng}$ of oligodT primers, $15 \mathrm{U}$ of AMV reverse transcriptase, $20 \mathrm{U}$ of RNasin (Promega) and $0.5 \mathrm{mM}$ dNTPs in a final volume of $20 \mu \mathrm{l}$. The reaction was incubated at $42^{\circ} \mathrm{C}$ for $60 \mathrm{~min}$. The cDNA product was amplified by PCR in a final volume of $50 \mu \mathrm{l}$ containing $3 \mu \mathrm{l}$ of cDNA, $5 \mu \mathrm{l}$ of 10X PCR buffer, $1 \mathrm{U}$ Taq polymerase (Promega), $0.2 \mathrm{mM} /$ dNTP and 25 pmol of each primer. Thirty-five cycles of PCR were performed in a PE 2400 (Perkin-Elmer, USA) as follows: $94^{\circ} \mathrm{C}, 30 \mathrm{sec}$; annealing temperature, $40 \mathrm{sec} ; 72^{\circ} \mathrm{C}, 40 \mathrm{sec}$ and the PCR product was analyzed on a $2 \%$ agarose gel. $B$-actin was used as a positive control. Primer sequences and the amplified fragment sizes are listed in Table I.

Immunoblotting. The cells in each group were collected by centrifugation $72 \mathrm{~h}$ after treatment with $\mathrm{As}_{2} \mathrm{O}_{3}$, the supernatant were removed, then the precipitation were washed twice with PBS. After removing the supernatant, the cells were lysed with $100 \mu 1$ lysis buffer and $1 \mu 1$ protease inhibitor per $1 \times 10^{6}$ cells. The cells were fully dispersed and the tubes were slanted for $30 \mathrm{~min}$ at $4^{\circ} \mathrm{C}$, then they were centrifuged at $10000 \mathrm{rpm}$ for $10 \mathrm{~min}$ at $4^{\circ} \mathrm{C}$ and conserved at -20 or $-80^{\circ} \mathrm{C}$ for further analysis. The protein content were measured by Bradford method (Coomassie brilliant blue method). Total protein $(30 \mu \mathrm{g})$ in each treatment group were loaded on $8 \%$ SDS-PAGE and transferred electrophoretically onto a nitrocellulose membrane. The nitrocellulose membrane were rinsed with Double-distilled water several times, protein wells and molecular weight standards were marked with a soft pencil. The membranes were blocked in $10 \mathrm{X}$ blocking buffer $(10 \mathrm{ml}$ PBS containing $1 \mathrm{~g}$ non-fat dry milk) for $2 \mathrm{~h}$, and then incubated in a wet box at $4{ }^{\circ} \mathrm{C}$ for $36 \mathrm{~h}$ with mouse anti-human monoclonal antibody (diluted 1:750). After washing with PBS, the membranes were incubated in a shaker incubater with horseradish peroxidase labeled goat anti-mouse IgG (diluted 1:3000) at room temperature for $2 \mathrm{~h}$. Immunocomplexes were visualized using the ECL Western blotting detection system according to the manufacturer's protocol (Amersham Biosciences, UK). We used the mouse monoclonal h-actin (Sigma) antibody as a loading control for Western blots at dilution of $1: 1000$.
DNMT enzyme activity assay. DNMT enzyme activity was assayed in nuclear extracts from untreated cells and cells treated with $\mathrm{As}_{2} \mathrm{O}_{3}$. Nuclear extracts were prepared as described above and $5 \mu \mathrm{g}$ protein lysate was added to $200 \mu \mathrm{l}$ of an assay mixture consisting of $20 \mathrm{mmol} / \mathrm{l}$ Tris- $\mathrm{HCl}, \mathrm{pH} 7.4$, $5 \mathrm{mmol} / \mathrm{l}$ EDTA, 25\% glycerol, $0.5 \%$ Triton X-100, $1 \mathrm{mmol} / \mathrm{l}$ dithiothreitol, $0.2 \mathrm{mmol} / 1$ phenylmethylsulfonyl fluoride, $5 \mu \mathrm{Ci}$ of S-adenosyl-1-(methyl-3H)methionine (12 Ci/mmol), $4 \mu \mathrm{g}$ of poly (dI-dC) and $200 \mu \mathrm{g} / \mathrm{ml}$ bovine serum albumin and incubated at $37^{\circ} \mathrm{C}$ for $2 \mathrm{~h}$. Reactions were subjected to $10 \%$ trichloroacetic acid precipitation and filtration through $\mathrm{GF} / \mathrm{C}$ filters (Whatman, Ltd., Maidstone, UK). The precipitate was dried and then washed with $10 \%$ trichloroacetic acid (10\%) and $70 \%$ ethanol. Filters were placed in scintillation mixture, and DNMT activity was determined by scintillation counting (Tricarb 2500TR, Packard, Meriden, USA). All assays were performed in triplicate. Background levels were determined in the absence of template DNA.

Statistical analysis. Normally distributed continuous variables were compared by one-way analysis of variance (ANOVA). When a significant difference between groups was apparent, multiple comparisons of means were performed using the Bonferroni procedure with type-I error adjustment. Data are presented as means \pm SD. All statistical assessments were two-sided and evaluated at the 0.05 level of significant difference. Statistical analyses were performed using SPSS 15.0 statistics software (SPSS Inc., Chicago, IL).

\section{Results}

CpG methylation of CDKN2B or CDKN2A in Molt4, MUTZ-1, U937, U266 and CA46 cell lines. The methylation status of CpG islands of CDKN2B and CDKN2A genes was examined in Molt4, U937, MUTZ-1, U266 and CA46 cell lines. We demonstrated that the CDKN2B promoter was hypermethylated in Molt4 and MUTZ-1 cell lines while the CDKN2A was hypermethylated in U937, U266 and CA46 cell lines (Figs. 1 and 2).

$\mathrm{As}_{2} \mathrm{O}_{3}$-induced demethylation of $\mathrm{Cp} G$ islands of $C D K N 2 \mathrm{~B}$ or CDKN2A in Molt4, MUTZ-1, U937, U266 and CA46 cell lines. The CDKN2B and CDKN2A genes were either partially or completely demethylated in Molt4, MUTZ-1, U937, U266 and CA46 cell lines after treatment with $0.5,1.0$ or $2.0 \mu \mathrm{mol} / \mathrm{l}$ $\mathrm{As}_{2} \mathrm{O}_{3}$ for $72 \mathrm{~h}$. We showed a significant decrease in the methylation specific bands of the CDKN2B and the CDKN2A genes in cells treated with $2 \mu \mathrm{mol} / 1$ of $\mathrm{As}_{2} \mathrm{O}_{3}$ for $72 \mathrm{~h}$. In contrast, there was an increase in the non-methylation specific bands of these genes in cells treated with $2 \mu \mathrm{mol} / 1$ of $\mathrm{As}_{2} \mathrm{O}_{3}$ for $72 \mathrm{~h}$ (Figs. 3-7). $\mathrm{As}_{2} \mathrm{O}_{3}$-mediated changes in the methylation patterns of $\mathrm{CpG}$ islands in the $\mathrm{CDKN} 2 \mathrm{~B}$ and $\mathrm{CDKN} 2 \mathrm{~A}$ genes were examined by DNA sequence analysis. We showed that DNA sulfuration in $2.0 \mu \mathrm{mol} / 1 \mathrm{As}_{2} \mathrm{O}_{3}$-treated Molt4 cells resulted in conversion of all cytosines in the $\mathrm{CpG}$ dinucleotides of the CDKN2B gene to thymidines. Untreated cells showed no change in these cytosine residues (Fig. 8). These data confirm that $\mathrm{As}_{2} \mathrm{O}_{3}$ treatment resulted in demethylation of the hypermethylated $\mathrm{CpG}$ islands of the CDKN2B 

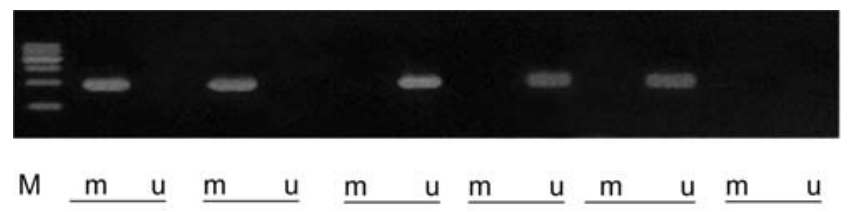

$\begin{array}{llllll}1 & 2 & 3 & 4 & 5 & 6\end{array}$

Figure 1. Methylation status of the CpG islands in the CDKN2B gene promoter in Molt4, MUTZ-1, U937, U266 and CA46 cell lines. The CDKN2B promoter was hypermethylated in Molt4 and MUTZ-1 cell lines but not in U937, U266 and CA46 cell lines. Lane M, marker (100 bp DNA ladder); Lane 1, Molt4 cell line; Lane 2, MUTZ-1 cell line; Lane 3, U937 cell line; Lane 4, U266 cell line; Lane 5, CA46 cell line; Lane 6, blank control. m, methylated band (194 bp); u, unmethylated band (196 bp).

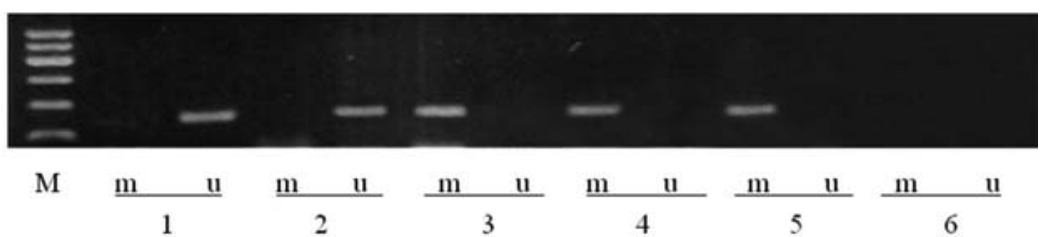

Figure 2. Methylation status of the CpG islands in the CDKN2A gene promoter in Molt4, MUTZ-1, U937, U266 and CA46 cell lines. The CDKN2A promoter was hypermethylated in U937, U266 and CA46 cell lines but not in Molt4 and MUTZ-1 cell lines. Lane M, marker (100 bp DNA ladder); Lane 1, Molt4 cell line; Lane 2, MUTZ-1 cell line; Lane 3, U937 cell line; Lane 4, U266 cell line; Lane 5, CA46 cell line; Lane 6, blank control. m, methylated band (150 bp); u, unmethylated band (151 bp).

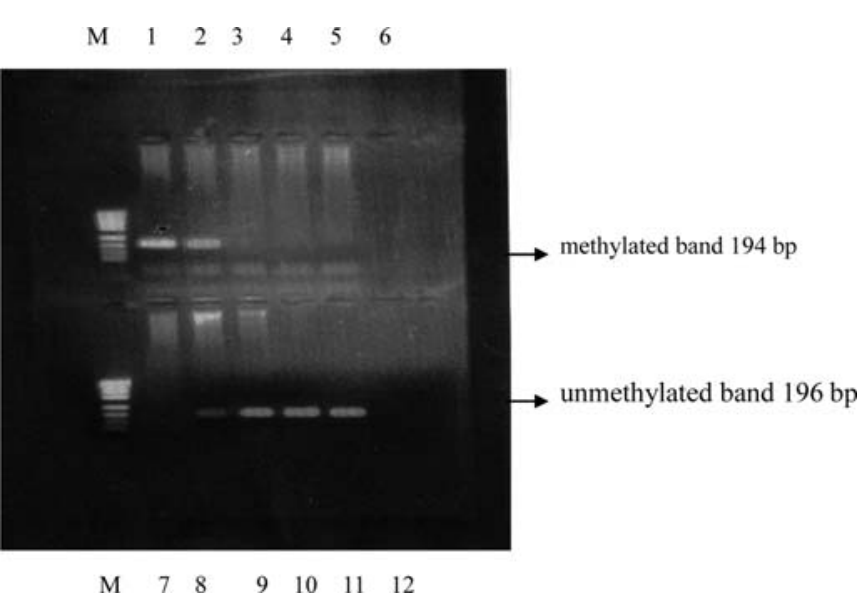

Figure 3. Methylation status of the $\mathrm{CpG}$ islands in the CDKN2B gene promoter in Molt4 cells. The CDKN2B gene promoter was partially or fully demethylated in Molt4 cells treated with 0.5, 1.0 and $2.0 \mu \mathrm{mol} / 1 \mathrm{As}_{2} \mathrm{O}_{3}$ for $72 \mathrm{~h}$. The methylation specific band was diminished in cells treated with 1.0 and $2.0 \mu \mathrm{mol} / 1$ of $\mathrm{As}_{2} \mathrm{O}_{3}$ for $72 \mathrm{~h}$. In contrast, the unmethylation specific band of CDKN2B gene was enhanced after treatment with $0.5-2.0 \mu \mathrm{mol} / 1$ of $\mathrm{As}_{2} \mathrm{O}_{3}$ for $72 \mathrm{~h}$. Lane M, puc 19 digested markers; Lanes 1 and 7, druguntreated groups; Lanes 2 and 8, 0. $5 \mu \mathrm{mol} / 1 \mathrm{As}_{2} \mathrm{O}_{3}$ groups; Lanes 3 and 9, $1.0 \mu \mathrm{mol} / 1 \mathrm{As}_{2} \mathrm{O}_{3}$ groups; Lanes 4 and $10,2.0 \mu \mathrm{mol} / 1 \mathrm{As}_{2} \mathrm{O}_{3}$ groups; Lanes 5 and 11 , control groups of normal lymphocytes were isolated from human bone marrow cells of spina iliaca posterior superior; Lanes 6 and 12, blank control groups. m, methylated band (194 bp); u, unmethylated band (196 bp).

gene in Molt4 cells. We also demonstrated (Fig. 9) that DNA sulfuration in $2.0 \mu \mathrm{mol} / 1 \mathrm{As}_{2} \mathrm{O}_{3}$-treated $\mathrm{U} 937$ cells resulted in conversion of all cytosines in $\mathrm{CpG}$ dinucleotides of the CDKN2A gene to thymidines. Untreated cells showed no change in these cytosine residues. These data confirm that $\mathrm{As}_{2} \mathrm{O}_{3}$ treatment resulted in demethylation of the hypermethylated CpG islands of the CDKN2A gene in U937 cells.

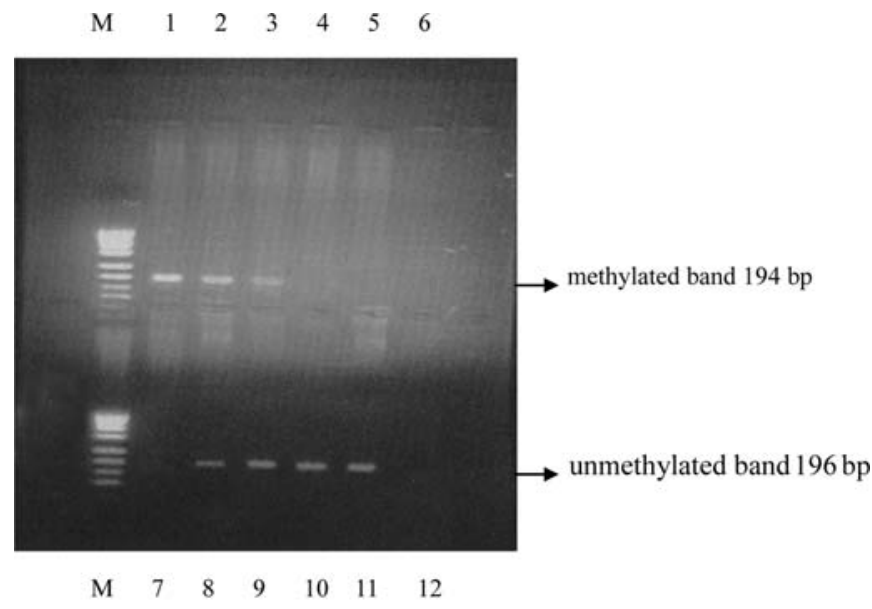

Figure 4. Methylation status of the $\mathrm{CpG}$ islands in the CDKN2B gene promoter in MUTZ-1 cell line. The CDKN2B gene promoter was partly or fully demethylated in MUTZ-1 cells treated with $0.5,1.0$ and $2.0 \mu \mathrm{mol} / 1 \mathrm{As}_{2} \mathrm{O}_{3}$ for $72 \mathrm{~h}$. The methylation specific band was diminished in cells treated with $2.0 \mu \mathrm{mol} / 1$ of $\mathrm{As}_{2} \mathrm{O}_{3}$ for $72 \mathrm{~h}$. In contrast, the unmethylation specific band of CDKN2B gene was enhanced after treatment with 0.5-2.0 $\mu \mathrm{mol} / 1$ of $\mathrm{As}_{2} \mathrm{O}_{3}$ for $72 \mathrm{~h}$. Lane M, puc 19 digested markers; Lanes 1 and 7, drug-untreated groups; Lanes 2 and 8, $0.5 \mu \mathrm{mol} / 1 \mathrm{As}_{2} \mathrm{O}_{3}$ groups; Lanes 3 and 9, $1.0 \mu \mathrm{mol} / 1$ $\mathrm{As}_{2} \mathrm{O}_{3}$ groups; Lanes 4 and $10,2.0 \mu \mathrm{mol} / 1 \mathrm{As}_{2} \mathrm{O}_{3}$ groups; Lane 5 and 11 , control groups of normal lymphocytes were isolated from human bone marrow cells of spina iliaca posterior superior; Lanes 6 and 12, blank control groups. m, methylated band (194 bp); u, unmethylated band (196 bp).

$\mathrm{As}_{2} \mathrm{O}_{3}$-induced reactivation of $\mathrm{CDKN} 2 \mathrm{~B}$ or $\mathrm{CDKN} 2 \mathrm{~A}$ mRNA expression. We showed (Fig. 10A and B) that Molt4 and U937 cells treated with different concentrations $(0,0.5,1$ and $2 \mu \mathrm{mol} / \mathrm{l}$ ) of $\mathrm{As}_{2} \mathrm{O}_{3}$ for $72 \mathrm{~h}$ showed alterations in their CDKN2B and CDKN2A mRNA levels. CDKN2B expression was silenced in untreated Molt4 cells while CDKN2A expression was silenced in untreated U937 cells. We showed 


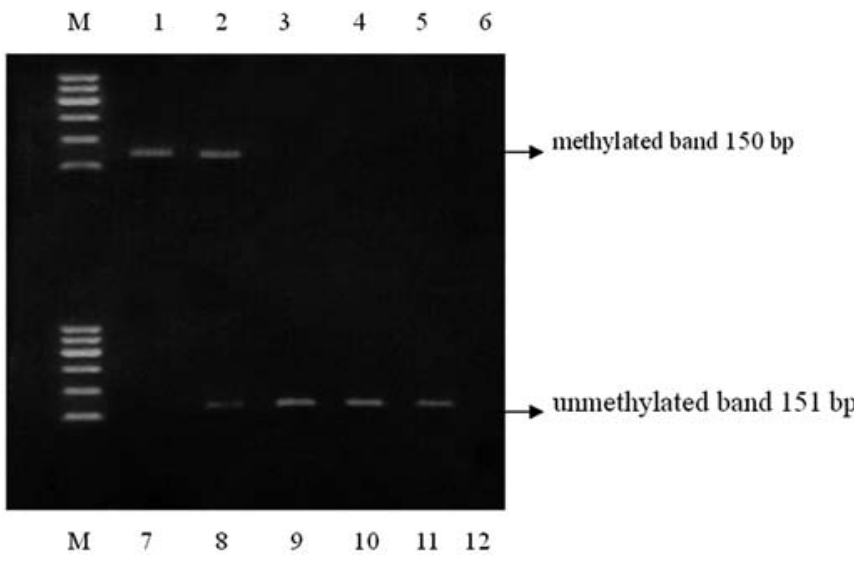

Figure 5. The methylation status of the $\mathrm{CpG}$ islands in the CDKN2A gene promoter in U937 cells. The CDKN2A gene was partly or fully demethylated in U937 cells treated with $0.5,1.0$ and $2.0 \mu \mathrm{mol} / 1 \mathrm{As}_{2} \mathrm{O}_{3}$ for $72 \mathrm{~h}$. The methylation specific band was diminished in cells treated with 1.0 and $2.0 \mu \mathrm{mol} / 1$ of $\mathrm{As}_{2} \mathrm{O}_{3}$ for $72 \mathrm{~h}$. In contrast, the unmethylation specific band of CDKN2A gene was enhanced after treatment with $0.5-2.0 \mu \mathrm{mol} / 1$ of $\mathrm{As}_{2} \mathrm{O}_{3}$ for $72 \mathrm{~h}$. Lane M, marker (100 bp DNA ladder); Lanes 1 and 7, druguntreated groups; Lanes 2 and 8, $0.5 \mu \mathrm{mol} / 1 \mathrm{As}_{2} \mathrm{O}_{3}$ groups; Lanes 3 and 9, $1.0 \mu \mathrm{mol} / 1 \mathrm{As}_{2} \mathrm{O}_{3}$ groups; Lanes 4 and 10, $2.0 \mu \mathrm{mol} / 1 \mathrm{As}_{2} \mathrm{O}_{3}$ groups; Lanes 5 and 11, control groups of normal lymphocytes; Lanes 6 and 12, blank control. $\mathrm{m}$, methylated band (150 bp); u, unmethylated band (151 bp).

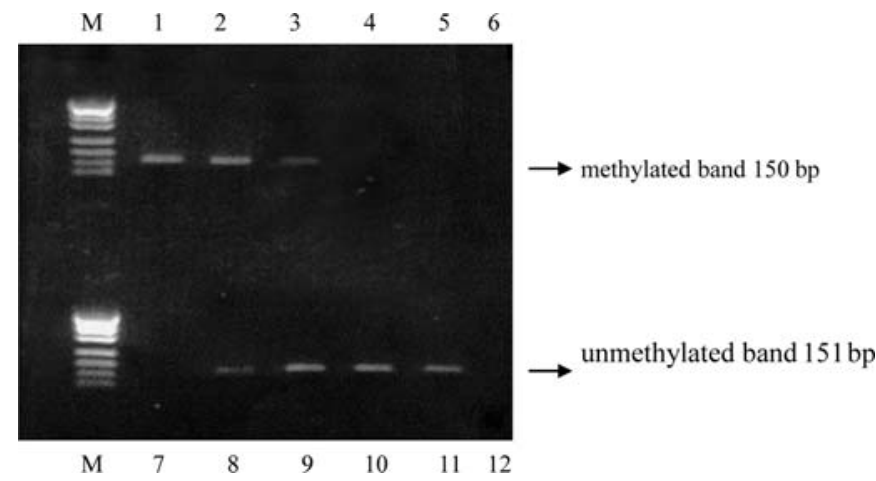

Figure 6. Methylation status of the $\mathrm{CpG}$ islands in the CDKN2A gene promoter in U266 cells. The CDKN2A gene was partly or fully demthylated in U266 cells treated with $0.5,1.0$ and $2.0 \mu \mathrm{mol} / 1 \mathrm{As}_{2} \mathrm{O}_{3}$ for $72 \mathrm{~h}$. The methylation specific band was diminished in cells treated with $2.0 \mu \mathrm{mol} / 1$ of $\mathrm{As}_{2} \mathrm{O}_{3}$ for $72 \mathrm{~h}$. In contrast, the unmethylation specific band of CDKN2A gene was enhanced after treatment with $0.5-2.0 \mu \mathrm{mol} / 1$ of $\mathrm{As}_{2} \mathrm{O}_{3}$ for $72 \mathrm{~h}$. Lane M, puc 19 digested markers; Lanes 1 and 7, drug-untreated groups; Lanes 2 and 8, 0. $5 \mu \mathrm{mol} / 1 \mathrm{As}_{2} \mathrm{O}_{3}$ groups; Lanes 3 and 9, $1.0 \mu \mathrm{mol} / 1 \mathrm{As}_{2} \mathrm{O}_{3}$ groups; Lanes 4 and 10, $2.0 \mu \mathrm{mol} / 1 \mathrm{As}_{2} \mathrm{O}_{3}$; Lanes 5 and 11, control groups of normal lymphocytes; Lanes 6 and 12, blank control. m, methylated band (150 bp); u, unmethylated band (151 bp).

(Fig. 10C and D) a dose-dependent increase in CDKN2B or CDKN2A expression in $\mathrm{As}_{2} \mathrm{O}_{3}$-treated Molt4 and U937 cells when compared with untreated cells $(\mathrm{P}<0.001)$. These results suggest the possibility of $\mathrm{As}_{2} \mathrm{O}_{3}$-mediated reactivation of methylation-silenced CDKN2B or CDKN2A genes in different hematological malignant cell lines.

Western blot analysis of CDKN2B or CDKN2A. We used Western blot analysis to demonstrate that CDKN2B or CDKN2A protein levels were increased in Molt4 and U937

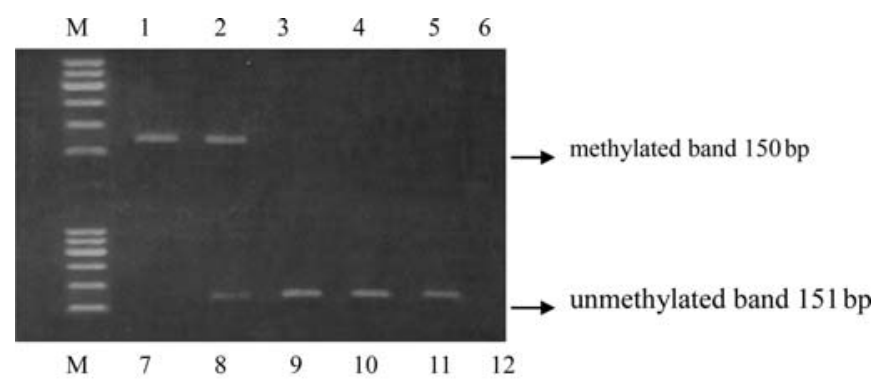

Figure 7. Methylation status of the $\mathrm{CpG}$ islands in the CDKN2A gene promoter in CA46 cells. The CDKN2A gene was partly or fully demethylated in CA46 cells treated with $0.5,1.0$ and $2.0 \mu \mathrm{mol} / 1 \mathrm{As}_{2} \mathrm{O}_{3}$ for $72 \mathrm{~h}$. The methylation specific band was diminished in cells treated with 1.0 and $2.0 \mu \mathrm{mol} / 1 \mathrm{As}_{2} \mathrm{O}_{3}$ for $72 \mathrm{~h}$. In contrast, the unmethylation specific band of CDKN2A gene was enhanced after treatment with $0.5-2.0 \mu \mathrm{mol} / 1$ of $\mathrm{As}_{2} \mathrm{O}_{3}$ for $72 \mathrm{~h}$. Lane M, marker (100 bp DNA ladder); Lanes 1 and 7, drug-untreated groups; Lanes 2 and 8, $0.5 \mu \mathrm{mol} / 1 \mathrm{As}_{2} \mathrm{O}_{3}$ groups; Lanes 3 and 9, $1.0 \mu \mathrm{mol} / 1$ $\mathrm{As}_{2} \mathrm{O}_{3}$ groups; Lanes 4 and 10, $2.0 \mu \mathrm{mol} / 1 \mathrm{As}_{2} \mathrm{O}_{3}$ groups; Lanes 5 and 11, control groups of normal lymphocytes; Lanes 6 and 12, blank control. $\mathrm{m}$, methylated band (150 bp); u, unmethylated band (151 bp).

cell lines treated with $0.5,1$ and $2 \mu \mathrm{mol} / 1$ of $\mathrm{As}_{2} \mathrm{O}_{3}$ for $72 \mathrm{~h}$ (Fig. 11A and B), Untreated cells showed undetectable CDKN2B and CDKN2A expression. These data indicate that $\mathrm{As}_{2} \mathrm{O}_{3}$ was able to restore partially or fully restore the expression levels of the CDKN2B or CDKN2A genes.

$\mathrm{As}_{2} \mathrm{O}_{3}$ inhibits DNMT enzyme activity and DNMTs mRNA expression. In order to investigate the mechanism of $\mathrm{As}_{2} \mathrm{O}_{3^{-}}$ induced DNA demethylation, we measured DNMT enzyme activity and DNMT mRNA levels in $\mathrm{As}_{2} \mathrm{O}_{3}$-treated cells. Using nuclear extracts from untreated and $\mathrm{As}_{2} \mathrm{O}_{3}$-treated cells as the source of DNMT and polydeoxyinosine-deoxycytosine as the substrate, we showed that $\mathrm{As}_{2} \mathrm{O}_{3}$ inhibited DNMT activity in U266 cells in a dose-dependent manner (Fig. 12A). We also showed a dose-dependent inhibition of DNMT1, DNMT3a and DNMT3b mRNA levels in $\mathrm{As}_{2} \mathrm{O}_{3^{-}}$ treated cells $(\mathrm{P}<0.001)$. DNMT1 mRNA levels were 8.7-fold higher in untreated U266 cells when compared with the normal control group $(\mathrm{P}<0.001$; Fig. 12B). DNMT3a mRNA levels were 6.5-fold higher in untreated U266 cells when compared with the normal control group $(\mathrm{P}<0.001$; Fig. 12C), while the mRNA expression of DNMT3b in untreated U266 cells was 4.9-fold higher when compared with the normal control group $(\mathrm{P}<0.001$; Fig. 12D). There was a dosedependent inhibition of DNMT1, DNMT3a and DNMT3b mRNA levels in $\mathrm{As}_{2} \mathrm{O}_{3}$-treated cells $(\mathrm{P}<0.001)$.

\section{Discussion}

CDKN2B and CDKN2A genes are important negative regulators of the cell cycle and bring about cell cycle arrest at G1 by interfere with the binding of CDKs 4/6, with Cyclin D and inhibiting phosphorylation of $\mathrm{Rb}$ (13). CDKN2B and CDKN2A are thought to be tumor suppressors whose loss of function in tumors results in aberrant phosphorylation of retinoblastoma and accelerated cell growth (14). Aberrant methylation of $\mathrm{CpG}$ islands (extending from the promoter 
A:

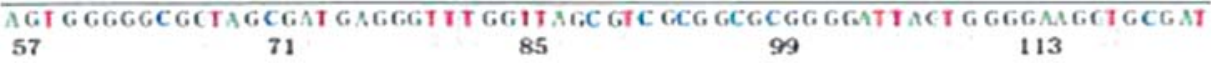

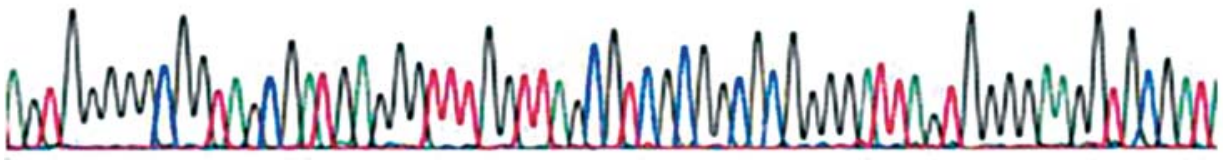

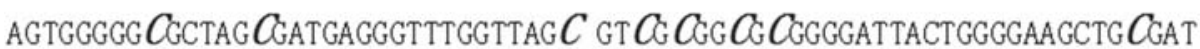

B:
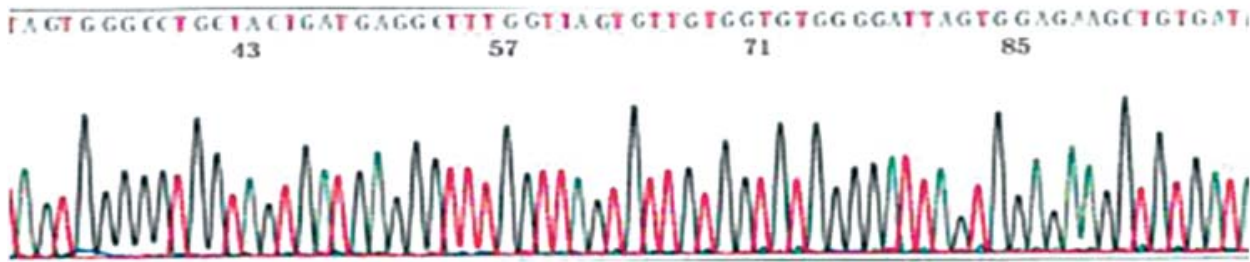

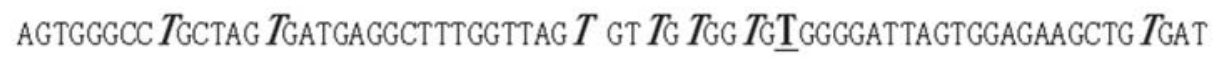

Figure 8. T-A clone and DNA sequence analysis methylation of CDKN2B gene. (A) The cytosines in the CpG dinucleotides in untreated Molt4 cells with sulfuration remain unchanged (italic shadowy section); (B) all cytosines in $2.0 \mu \mathrm{mol} / 1 \mathrm{As}_{2} \mathrm{O}_{3}$ treated Molt4 cells with sulfuration have been converted to thymidine showing that the pattern of cytosine methylation has been reversed.

A

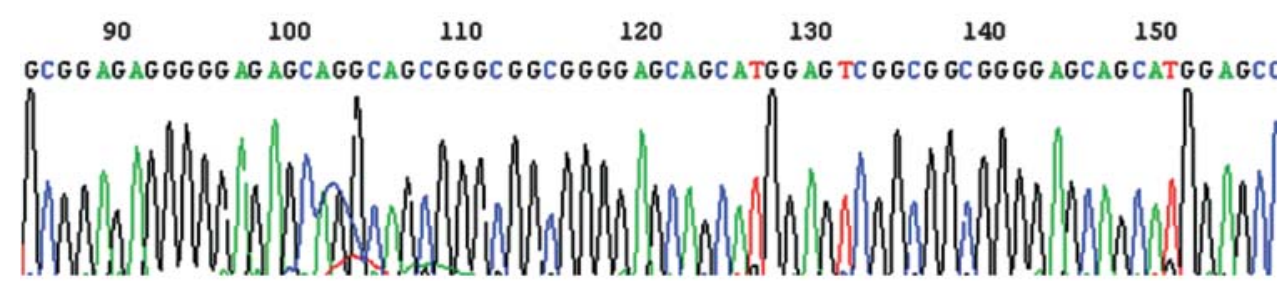

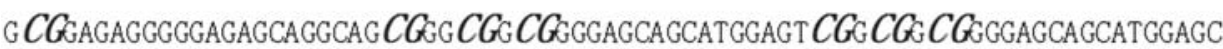

B:

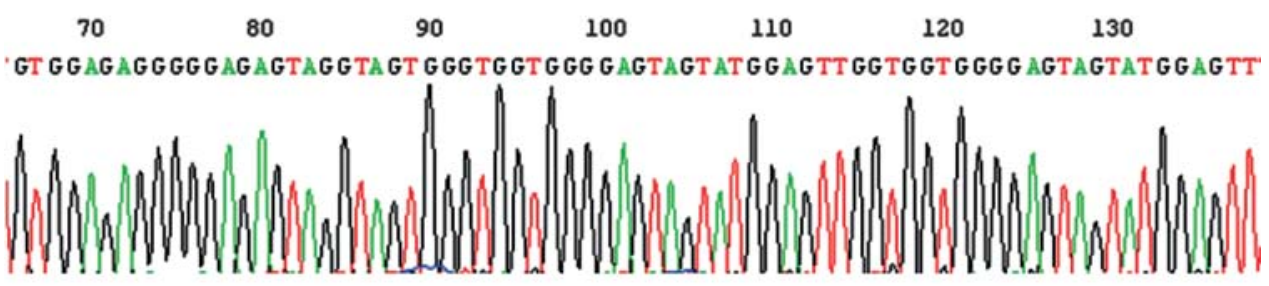

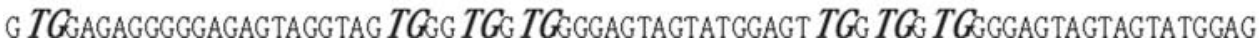

Figure 9. T-A clone and DNA sequence analysis methylation of CDKN2A gene. (A) The cytosines in the CpG dinucleotides in untreated U937 cells with sulfuration remain unchanged (italic shadowy section); (B) all cytosines in $2.0 \mu \mathrm{mol} / 1 \mathrm{As}_{2} \mathrm{O}_{3}$ treated U937 cells with sulfuration have been converted to thymidine showing that the pattern of cytosine methylation has been reversed.

region of these genes to exon 1) is an important mechanism by which the CDKN2A and the CDKN2B genes are transcriptionally inactivated (15) and this phenomenon has been reported in a number of human cancers (13-17).
In this study, we demonstrated that the promoter of the CDKN2B gene was hypermethylated in Molt4 and MUTZ-1 cells and the promoter of the CDKN2A gene was hypermethylated in U937, U266 and CA46 cells. We also demon- 
A

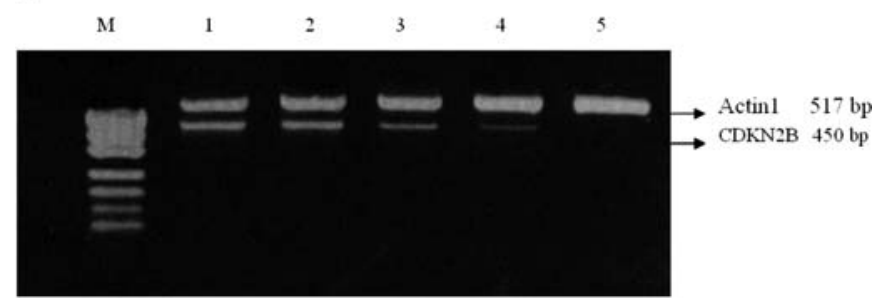

C

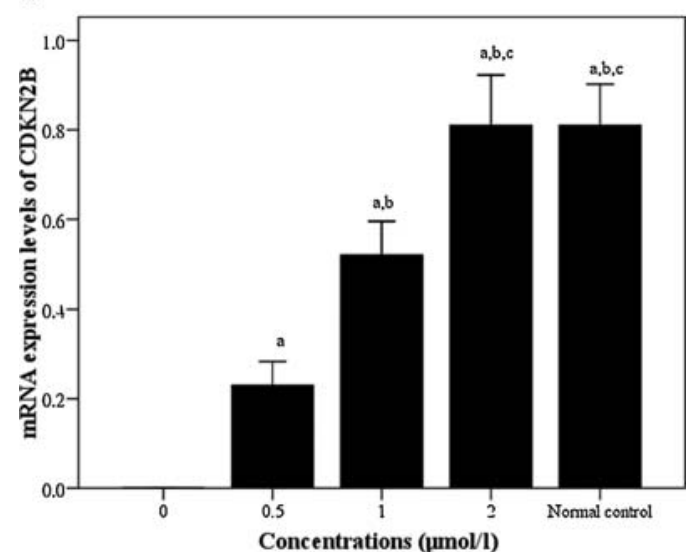

B

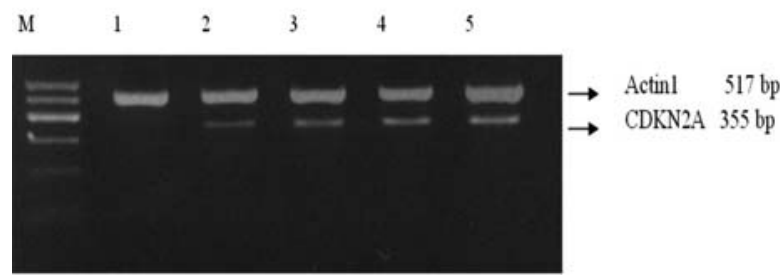

D

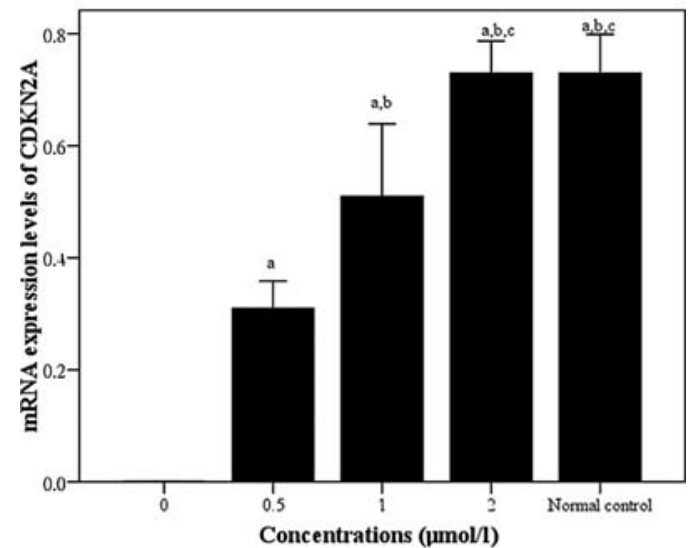

Figure 10. CDKN2B and CDKN2A mRNA levels in Molt4 and U937 cells treated with different concentrations $\left(0,0.5,1\right.$ and $2 \mu$ mol/l) of As $\mathrm{O}_{3}$ for $72 \mathrm{~h}$. (A) Molt 4 cells were treated with different concentrations $(0,0.5,1$ and $2 \mu \mathrm{mol} / \mathrm{l})$ of $\mathrm{As}_{2} \mathrm{O}_{3}$ for $72 \mathrm{~h}$. (B) U937 cells were treated with different concentrations $(0$, $0.5,1$ and $2 \mu \mathrm{mol} / \mathrm{l})$ of $\mathrm{As}_{2} \mathrm{O}_{3}$ for $72 \mathrm{~h}$. (C) Alterations of mRNA expression levels of CDKN2B gene in Molt4 cells treated with different concentrations (0, $0.5,1$ and $2 \mu \mathrm{mol} / \mathrm{l})$ of $\mathrm{As}_{2} \mathrm{O}_{3}$ for $72 \mathrm{~h}$. (D) Alterations of mRNA expression levels of CDKN2A gene in U937 cells treated with different concentrations $(0$, $0.5,1$ and $2 \mu \mathrm{mol} / \mathrm{l}$ ) of $\mathrm{As}_{2} \mathrm{O}_{3}$ for $72 \mathrm{~h}$. Relative mRNA levels of CDKN2B and CDKN2A were determined by RT-PCR. The values presented are mean $\pm \mathrm{SD}$ $(n=3)$. (a) Indicates a statistically significant difference between the indicated group and the drug-untreated group. (b) Indicates a statistically significant difference between the indicated group and the $0.5 \mu \mathrm{mol} / 1 \mathrm{As}_{2} \mathrm{O}_{3}$ group. (c) Indicates a statistically significant difference between the indicated group and the $1 \mu \mathrm{mol} / 1 \mathrm{As}_{2} \mathrm{O}_{3}$ group. Pair-wise multiple comparisons between groups were determined using Bonferroni's test with $\alpha=0.001$ adjustment.

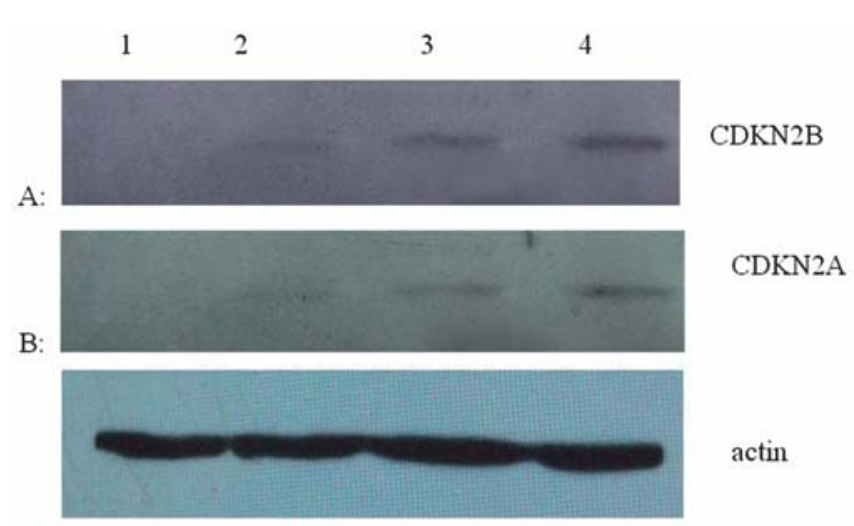

Figure 11. CDKN2B and CDKN2A protein levels in Molt4 and U937 cells treated with different concentrations $(0,0.5,1$ and $2 \mu \mathrm{mol} / 1)$ of $\mathrm{As}_{2} \mathrm{O}_{3}$ for 72 h. (A) Molt4 cells were treated with different concentrations $(0,0.5,1$ and $2 \mu \mathrm{mol} / \mathrm{l}$ ) of $\mathrm{As}_{2} \mathrm{O}_{3}$ for $72 \mathrm{~h}$; (B) U937 cells were treated with different concentrations $(0,0.5,1$ and $2 \mu \mathrm{mol} / \mathrm{l})$ of $\mathrm{As}_{2} \mathrm{O}_{3}$ for $72 \mathrm{~h}$.

strated undetectable mRNA levels in Molt4 and MUTZ-1 cells where the CDKN2B promoter was hypermethylated and undetectable CDKN2A mRNA levels in U937, UA266 and CA46 cells where the CDKN2A promoter was hypermethylated.
$\mathrm{As}_{2} \mathrm{O}_{3}$ is known to be effective in the treatment of promyelocytic leukemia by efficiently inducing apoptosis and inhibiting cell proliferation $(18,19)$. Although arsenic is known to be carcinogenic in humans, the mechanism of carcinogenicity remains unclear. Inorganic arsenic is detoxified in mammals via enzymatic conversion to monomethylated and dimethylated arsenic (20) in a reaction requiring SAM as a methyl donor and a methyltransferase enzyme such as Cyt19 (21). Since SAM is also an essential cofactor for a variety of DNMTs, arsenic exposure induces SAM depletion (8) along with increased levels of S-adenosyl homocysteine (SAH) which is known to be an effective inhibitor of DNMT activity.

We demonstrated that low concentrations of $\mathrm{As}_{2} \mathrm{O}_{3}$ induced demethylation of $\mathrm{CpG}$ islands in the promoters of the CDKN2B and CDKN2A genes in the Molt4, MUTZ-1, U937, U266 and CA46 cell lines. Demethylation of the CDKN2B and the CDKN2A genes caused an increase in their mRNA expression levels to levels comparable with those of the normal control group. This is an important finding suggesting that manipulation of methylation patterns can result in changes in the expression levels of tumor suppressor genes, which could have important clinical applications.

We previously studied p16 promoter methylation in a group of 82 adult leukemia patients and demonstrated that the p16 promoter was methylated in $39 \%$ of the patients. 
A

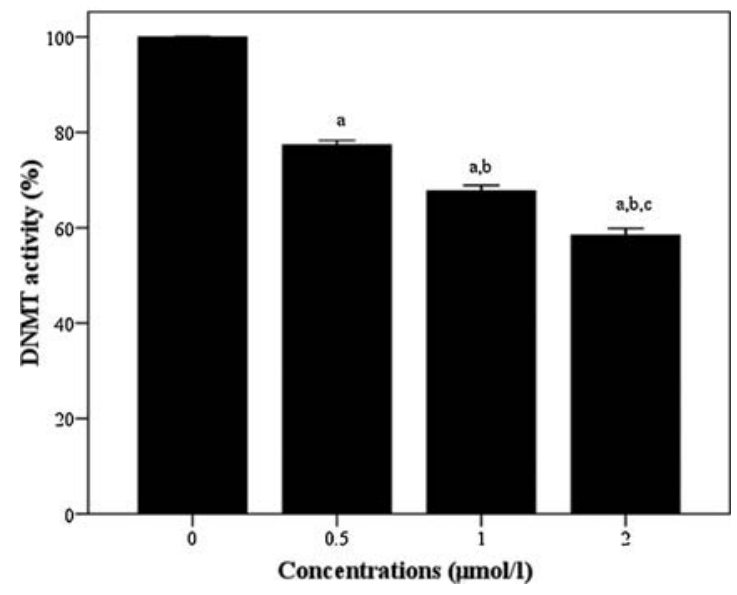

C
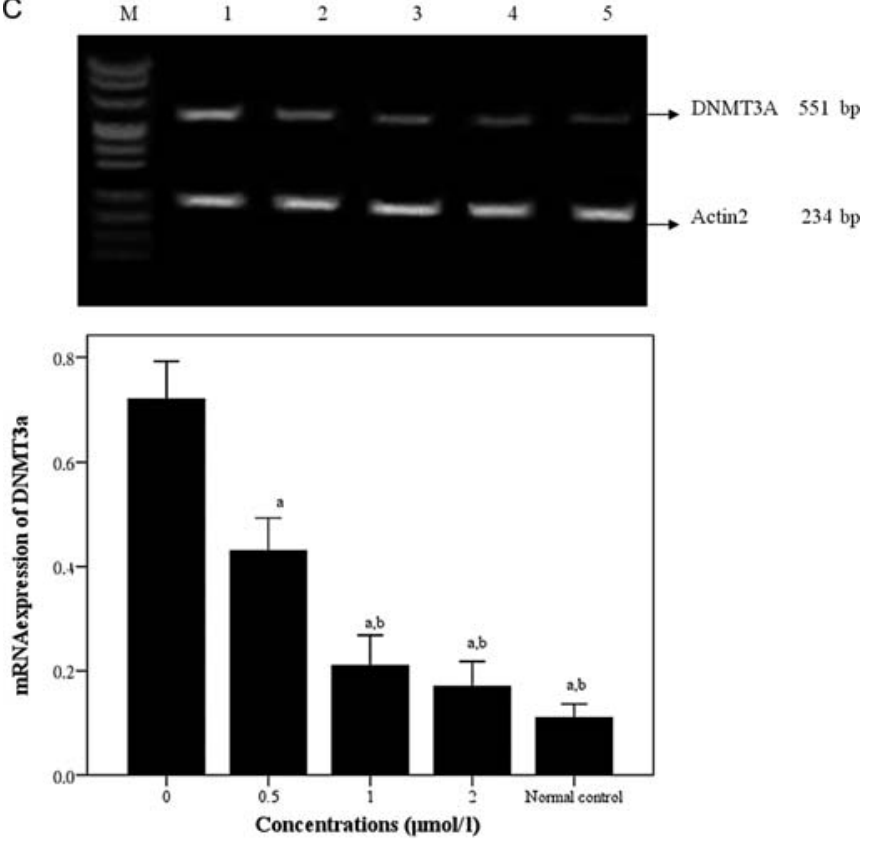
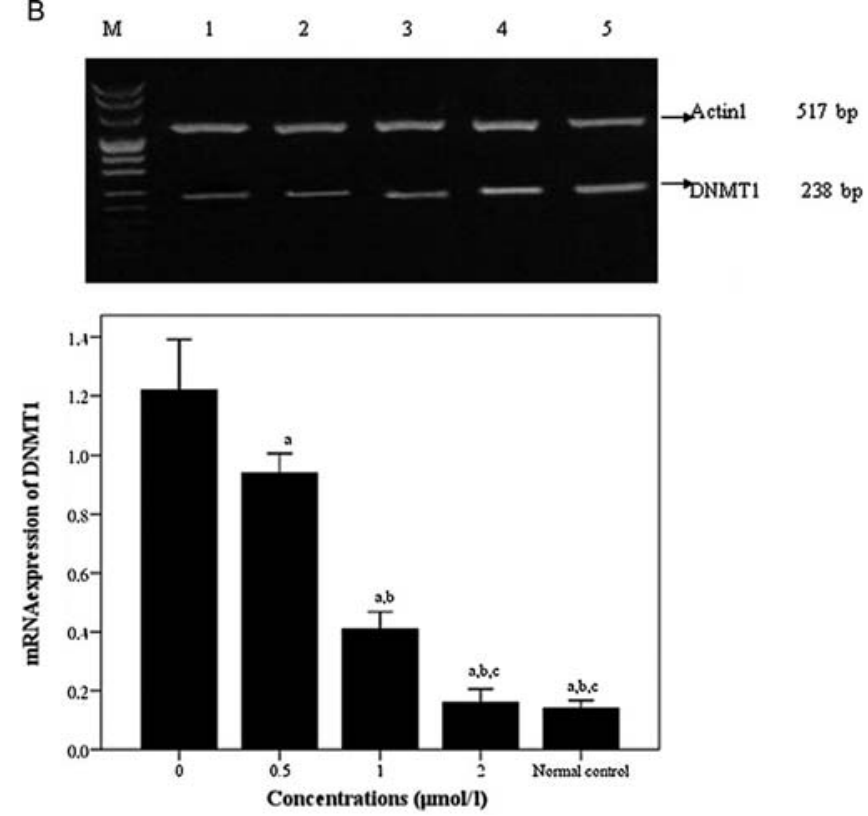

D
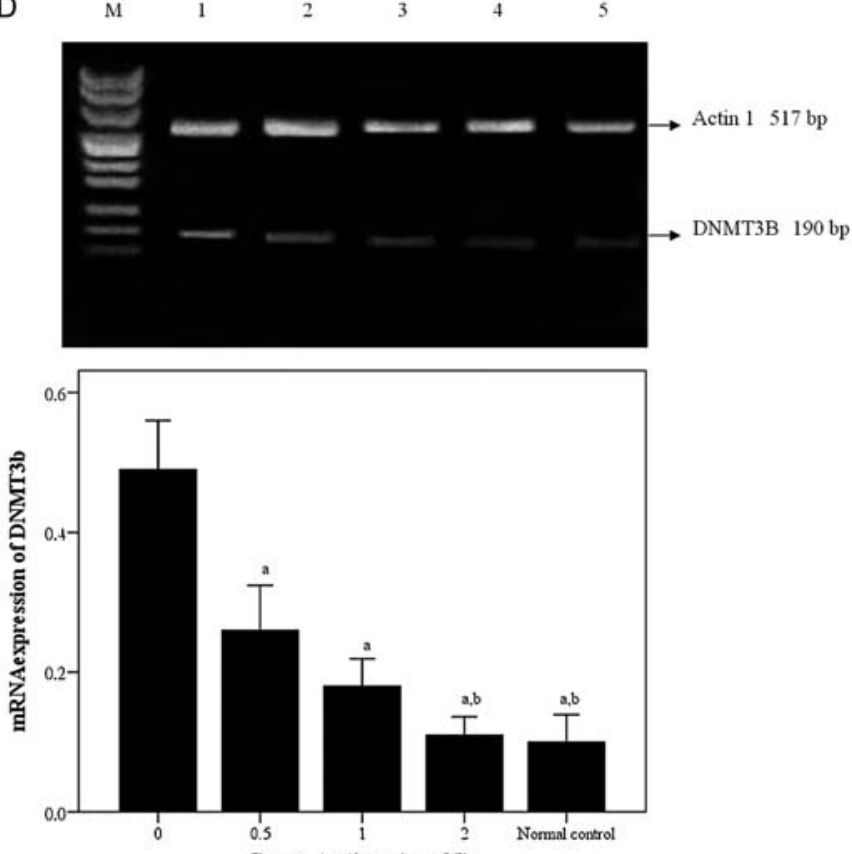

Concentrations (umol/ $)$

Figure 12. (A) Inhibition of DNMT activity by different concentrations of $\mathrm{As}_{2} \mathrm{O}_{3}$. (B-D) Alteration of mRNA expression of DNMT1, DNMT3a and DNMT3b in U266 cells treated with different concentrations $(0,0.5,1$ and $2 \mu \mathrm{mol} / \mathrm{l})$ of $\mathrm{As}_{2} \mathrm{O}_{3}$ for $72 \mathrm{~h}$. Relative mRNA levels of DNMT1, DNMT3A and DNMT3B were determined by RT-PCR. The values presented are mean \pm SD ( $=3$ ). (a) Indicates a statistically significant difference between the indicated group and the drug-untreated group. (b) Indicates a statistically significant difference between the indicated group and the $0.5 \mu$ mol/ 1 As $\mathrm{O}_{3}$ group. (c) Indicates a statistically significant difference between the indicated group and the $1 \mu \mathrm{mol} / 1 \mathrm{As}_{2} \mathrm{O}_{3}$ group. Pair-wise multiple comparisons between groups were determined using Bonferroni's test with $\alpha=0.001$ adjustment.

None of the control patients showed p16 promoter methylation (22). We also showed that the p16 gene was demethylated and activated in $\mathrm{As}_{2} \mathrm{O}_{3}$-treated $\mathrm{U} 266$ cells, along with a concomitant growth arrest of these cells at the G1 phase (23). We also showed p15 gene methylation in different malignant cell lines (24). Our current study extends these findings by expanding the repertoire of hematological malignant cell lines to correlate with the results of our previous clinical study (22). We plan to carry out flow cytometry to investigate cell cycle events in untreated and $\mathrm{As}_{2} \mathrm{O}_{3}$-treated cells in this study in order to determine the effects of CDKN2A and CDKN2B reactivation in all these cell lines. It could be informative to investigate the differential CDK inhibitor silencing and reactivation in different cell lines; why methylation of p15 gene occurs in certain tumor cell line, but some cell lines is occurred on p16 gene which is not explicit at present, further research is required.

Overexpression of DNMT1 and DNMT3a genes was previously reported to be an early event in hepatocarcinogenesis (25) and increased DNMT1 protein levels were 
reported to be a poor prognostic marker in $\mathrm{HCC}$ (26). Previous research showed that $\mathrm{As}_{2} \mathrm{O}_{3}$ suppressed DNMT1 mRNA levels specifically in HepG2 cells, while the expression of DNMT3a and DNMT3b remained unchanged (27). However, our results showed that, in addition to inhibiting DNMT activity, $\mathrm{As}_{2} \mathrm{O}_{3}$ also significantly down-regulated DNMT1, DNMT3a and DNMT3b mRNA levels in a dose-dependent manner in human hematological malignancies. We suggest that inhibition of DNMT activity is correlated with $\mathrm{As}_{2} \mathrm{O}_{3^{-}}$ mediated demethylation of $\mathrm{CpG}$ islands. Our future goals include an investigation of the mechanism of the $\mathrm{As}_{2} \mathrm{O}_{3}$ mediated transcriptional inhibition of DNMTs.

We recognize that the results presented in this study only pertain to in vitro cell culture systems and expect to confirm these results using in vivo studies as well as appropriate retrospective studies with patient samples.

In summary, we showed that low concentrations of $\mathrm{As}_{2} \mathrm{O}_{3}$ induced demethylation of the $\mathrm{CpG}$ islands in the CDKN2B and CDKN2A gene promoters, with a consequent reactivation of these silenced genes in human hematologic malignancies. This $\mathrm{As}_{2} \mathrm{O}_{3}$-induced demethylation is correlated with DNMT inhibition. Although $\mathrm{As}_{2} \mathrm{O}_{3}$ is known to be effective in the treatment of leukemias, especially acute promyelocytic leukemia, it has not been extensively used in the treatment of other human hematologic malignancies. Our data suggest that $\mathrm{As}_{2} \mathrm{O}_{3}$ works in a wide variety of hematological malignant cell lines and restores the expression of tumor suppressor genes via inhibition of DNMT mRNA levels, DNMT activity and hypomethylation of $\mathrm{CpG}$ islands in the tumor suppressor genes.

\section{Acknowledgements}

This study was supported by the Natural Science Foundation of Fujian Province and the Natural Science Foundation for Young Scientists of Fujian Health Department, China (Grant No. 2007-1-22).

\section{References}

1. Sherr CJ: Principles of tumor suppression. Cell 116: 235-246, 2004.

2. Park MT and Lee SJ: Cell cycle and cancer. J Biochem Mol Biol 36: 60-65, 2003.

3. Feinberg AP and Tycko B: The history of cancer epigenetics. Nat Rev Cancer 4: 143-153, 2004.

4. Herman JG and Baylin SB: Gene silencing in cancer in association with promoter hypermethylation. N Engl J Med 349: 2042-2054, 2003.

5. Tycko B: Epigenetic gene silencing in cancer. J Clin Invest 105 : 401-407, 2000

6. Esteller M, Fraga MF, Guo M, et al: DNA methylation patterns in hereditary human cancers mimic sporadic tumorigenesis. Hum Mol Genet 10: 3001-3007, 2001.

7. Perkins C, Kim CN, Fang G and Bhalla KN: Arsenic induces apoptosis of multidrug-resistant human myeloid leukemia cells that express $\mathrm{Bcr}-\mathrm{Abl}$ or overexpress MDR, MRP, Bcl-2 or Bcl-x(L). Blood 95: 1014-1022, 2000.

8. Zhao CQ, Young MR, Diwan BA, Coogan TP and Waalkes MP: Association of arsenic-induced malignant transformation with DNA hypomethylation and aberrant gene expression. Proc Natl Acad Sci USA 94: 10907-10912, 1997.
9. Subbarayan PR, Lima M and Ardalan B: Arsenic trioxide/ ascorbic acid therapy in patients with refractory metastatic colorectal carcinoma: a clinical experience. Acta Oncol 46: 557-561, 2007.

10. Sciandrello G, Caradonna F, Mauro M and Barbata G: Arsenicinduced DNA hypomethylation affects chromosomal instability in mammalian cells. Carcinogenesis 25: 413-417, 2004.

11. Detich N, Hamm S, Just G, Knox JD and Szyf M: The methyl donor S-Adenosylmethionine inhibits active demethylation of DNA: a candidate novel mechanism for the pharmacological effects of S-Adenosylmethionine. J Biol Chem 278: 20812-20820, 2003.

12. Herman JG, Graff JR, Myohanen S, Nelkin BD and Baylin SB: Methylation-specific PCR: a novel PCR assay for methylation status of CpG islands. Proc Natl Acad Sci USA 93: 9821-9826, 1996.

13. Cairns P, Mao L, Merlo A, et al: Rates of p16 (MTS1) mutations in primary tumors with 9p loss. Science 265: 415-417, 1994.

14. Merlo A, Herman JG, Mao L, et al: 5' CpG island methylation is associated with transcriptional silencing of the tumour suppressor p16/CDKN2/MTS1 in human cancers. Nat Med 1: 686-692, 1995.

15. Herman JG, Merlo A, Mao L, et al: Inactivation of the CDKN2/ p16/MTS1 gene is frequently associated with aberrant DNA methylation in all common human cancers. Cancer Res 55: 4525-4530, 1995

16. Gonzalez-Zulueta M, Bender CM, Yang AS, et al: Methylation of the $5^{\prime} \mathrm{CpG}$ island of the $\mathrm{p} 16 / \mathrm{CDKN} 2$ tumor suppressor gene in normal and transformed human tissues correlates with gene silencing. Cancer Res 55: 4531-4535, 1995.

17. Ng MH, Chung YF, Lo KW, Wickham NW, Lee JC and Huang DP: Frequent hypermethylation of p16 and p15 genes in multiple myeloma. Blood 89: 2500-2506, 1997.

18. Shao W, Fanelli M, Ferrara FF, et al: Arsenic trioxide as an inducer of apoptosis and loss of PML/RAR alpha protein in acute promyelocytic leukemia cells. J Natl Cancer Inst 90: 124-133, 1998.

19. Miller WH Jr, Schipper HM, Lee JS, Singer J and Waxman S: Mechanisms of action of arsenic trioxide. Cancer Res 62: 3893-3903, 2002

20. Cui X, Kobayashi Y, Hayakawa T and Hirano S: Arsenic speciation in bile and urine following oral and intravenous exposure to inorganic and organic arsenics in rats. Toxicol Sci 82: 478-487, 2004.

21. Hayakawa T, Kobayashi Y, Cui X and Hirano S: A new metabolic pathway of arsenite: arsenic-glutathione complexes are substrates for human arsenic methyltransferase Cyt19. Arch Toxicol 79: 183-191, 2005.

22. Fan LP, Shen JZ, Ye BG, et al: Detection of p16 gene methylation status in adult patients with acute leukemia by using n-MSP. J Exp Hematol 15: 258-261, 2007.

23. Fu HY, Sheng JZ, Sheng SF and Zhou HR: n-MSP detection of p16 gene demethylation and transcription in human multiple myeloma U266 cell line induced by arsenic trioxide. J Exp Hematol 15: 79-85, 2007.

24. Lin FA, Ye BG, Shen JZ, Zhou HR, Fu HY and Fan LP Detection of p15 gene methylation or deletion status in different malignant cell lines by using hemi-nested methylation specific polymerase chain reaction. J Exp Hematol 15: 382-386, 2007.

25. Saito Y, Kanai Y, Sakamoto M, Saito H, Ishii H and Hirohashi S: Expression of mRNA for DNA methyltransferases and methylCpG-binding proteins and DNA methylation status on $\mathrm{CpG}$ islands and pericentromeric satellite regions during human hepatocarcinogenesis. Hepatology 33: 561-568, 2001.

26. Saito Y, Kanai Y, Nakagawa T, Sakamoto M, Saito H, Ishii H and Hirohashi S: Increased protein expression of DNA methyltransferase (DNMT) 1 is significantly correlated with the malignant potential and poor prognosis of human hepatocellular carcinomas. Int J Cancer 105: 527-532, 2003.

27. Cui X, Wakai T, Shirai Y, Yokoyama N, Hatakeyama K and Hirano S: Arsenic trioxide inhibits DNA methyltransferase and restores methylation-silenced genes in human liver cancer cells. Hum Pathol 37: 298-311, 2006. 